\title{
Physiology and biochemistry of leaf bleaching in prematurely aging maple (Acer saccharinum L.) trees. II. Functional and molecular adjustment of PSII.
}

\author{
Hrvoje LePeduš ${ }^{1}$, LidiJa Begović ${ }^{2}$, Selma Mlinarić ${ }^{2}$, Domagoj ŠImić ${ }^{1}$, \\ IVNA ŠTOLFA ${ }^{2}$, NADA PARAĐIKOVIĆ ${ }^{3}$, ZvONIMIR UŽAREVIĆ ${ }^{4}$, VlatKA JuRKOVIĆ ${ }^{1}$, \\ VERA CESAR ${ }^{2 *}$ \\ ${ }^{1}$ Agricultural Institute Osijek, Južno predgrađe 17, HR-31000 Osijek, Croatia \\ ${ }^{2}$ Department of Biology, University of J. J. Strossmayer in Osijek, Trg Lj. Gaja 6, \\ HR-31000 Osijek, Croatia \\ ${ }^{3}$ Faculty of Agriculture, University of J. J. Strossmayer in Osijek, Trg Sv. Trojstva 3, \\ HR-31000 Osijek, Croatia \\ ${ }^{4}$ Faculty of Education, University of J. J. Strossmayer in Osijek, L. Jägera 9, \\ HR-31000 Osijek, Croatia
}

\begin{abstract}
In the present study we aimed to investigate physiological and molecular mechanisms of photosynthetic performance decline in prematurely aged bleached leaves of silver maple (Acer saccharinum L.) trees. We used in vivo chlorophyll $a$ fluorescence measurement to analyze changes in PSII photochemistry, relative abundance of photosynthetic proteins (D1, LHCII, Cyt ${ }_{f}$ and Rubisco LSU), relations between chlorophylls and their precursor protochlorophyllide as well as elemental composition of the leaves. Decreases in $\mathrm{Al}, \mathrm{Cr}$, $\mathrm{Cu}, \mathrm{Fe}, \mathrm{K}, \mathrm{Zn}$ and an increase in $\mathrm{S}$ concentrations were found in bleached leaves in comparison to healthy green ones. The bleached leaves were visually expressing symptoms characteristic of Fe deficiency. Further, they had considerably decreased chlorophyll contents and protochlorophyllide contents, overall photosynthetic activity and relative abundance of major photosynthetic proteins. All the results indicate that modifications in the molecular organization of photosynthetic electron-transport chain components in bleached leaves led to functional adaptation of the PSII achieved by modifications of some reaction centres (RCs), turning them from active to dissipative. This provided efficient adaptation of bleached leaves to high-light induced oxidative damage during summer.
\end{abstract}

Key words: Acer saccharinum, bleached leaves, chlorophyll, photosynthesis, premature aging

* Corresponding author, e-mail: vcesarus@yahoo.com

Copyright $^{\circledR} 2011$ by Acta Botanica Croatica, the Faculty of Science, University of Zagreb. All rights reserved. 


\begin{abstract}
Abbreviations: BCIP - 5-bromo-4-chloro-3-indolyl phosphate, BSA - bovine serum albumin, Chl $\boldsymbol{a}+\boldsymbol{b}$ - total chlorophylls, $\mathbf{C y t}_{\boldsymbol{f}}-$ cytochrome f, DTT - dithiothreitol, $\Delta \boldsymbol{F} / \boldsymbol{F}^{\prime}{ }_{\boldsymbol{m}}{ }^{-}$ effective quantum yield of the photosystem II, $\boldsymbol{F}_{\boldsymbol{0}}-$ minimal fluorescence yield, $\boldsymbol{F}_{\boldsymbol{m}}-$ maximal fluorescence yield, $\boldsymbol{F}_{v} / \boldsymbol{F}_{m}-$ maximum quantum yield of the photosystem II, FM - mass of fresh tissue, ICP-OES - inductively-coupled plasma optical emission spectroscopy, LHCII - light harvesting complex of photosystem II, NBT - nitroblue tetrazolium, OJIP test - chlorophyll $a$ fluorescence transient measurement, PChl - protochlorophyllide, PPFD - photosynthetically active photon flux density, PSII - photosystem II, RCs reaction centres, Rubisco LSU - large subunit of Rubisco, SDS - sodium dodecyl sulfate
\end{abstract}

\title{
Introduction
}

Silver maple (Acer saccharinum L.) is a widely distributed tree species. It constitutes sustainable resource for the production of maple syrup, wood and lately has been seen as good quality source for the production of biofuel (SHAPOURI and DUFFIELD 1993). Because of its marked tolerance to different kind of stresses, silver maple trees also have horticultural value and are often used for ornamentation of urban parks and landscapes (DAY et al., 2000, HARDIN et al., 2001). However, a considerable number of chlorotic silver maple trees were noticed in the city park of Osijek (Croatia) growing besides healthy silver maple trees with green leaves. Leaves in these trees of decreased vitality became bleached as early as late spring (May) and kept such status during the whole vegetation season. Such symptoms observed in trees of decreased vitality correlate with symptoms of premature aging, sometimes called decline, which is characterized by chlorosis of foliage (bleaching), crown thinning and tree dieback (Houston 1999). Decline could be caused by various abiotic, biotic and unknown factors which are the source of stress to a tree. Silver maple is sensitive to nutrient deficiency, e.g. iron deficiency will cause a distinctive pattern on the leaves - cells close to the veins are green and the rest of the leaf area is bleached (SINCLAIR et al. 1987). Such a pattern can be seen in the maple leaves we investigated here (UŽAREVIĆ et al. 2011).

Our previous investigation on the regulation of hydrogen peroxide level in silver maple bleached leaves revealed reduced antioxidative enzyme specific activity levels as well as decreased ascorbic acid content (UŽAREvić et al. 2011). Also, bleached leaves had lower levels of chlorophyll $a$, chlorophyll $b$, total carotenoids and $F_{v} / F_{m}$ value (maximum quantum yield of photosystem II) than green leaves. Premature aging involves various mechanisms of adaptation in plants including changes in cell structure, metabolism, degradation of macromolecules and changes in gene expression (JING et. al. 2003). PSII, which functions as water-plastoquinone oxidoreductase, is one of major regulatory components in photosynthetic apparatus (BARBER et al. 1997). Accordingly, we aimed to investigate changes in PSII photochemistry, relative abundance of major photosynthetic proteins (D1, LHCII, Cyt f $_{f}$ and Rubisco LSU), relations between chlorophyll and its precursor protochlorophyllide as well as leaf elemental composition in order to understand functional and molecular adjustments of PSII in bleached leaves.

\section{Materials and methods}

\section{Plant materials}

Branches from the lower parts of the crowns of ten different trees (five green and five bleached) of silver maple (Acer saccharinum) were sampled, put in a plastic bag and deliv- 
ered to the laboratory within one hour. Sampling was done in May 2008, in the city park in Osijek (Croatia) every day at 10.30 am. For all extractions, leaves were cut into small pieces without main veins and ground with liquid nitrogen in a mortar in order to obtain fine tissue powder.

\section{Determination of photosynthetic pigment content}

For determination of photosynthetic pigment content combined samples of 5 replicates for every leaf type were used. Fine tissue powder was extracted in absolute ice-cold acetone for 15 minutes at $+4{ }^{\circ} \mathrm{C}$ and centrifuged for 10 minutes at $3000 \mathrm{rpm}$. This procedure was repeated until the leaf material was completely uncoloured. The concentrations of total chlorophylls ( $\mathrm{Chl} a+b$ ) and protochlorophyllide (PChl) per mass of fresh tissue (FM) were determined spectrophotometrically (Specord 40, Analytic Jena, Germany) according to LiCHTENTHALER (1987).

\section{Protein extraction, SDS-PAGE and immunodetection of D1, LHCII and Rubisco LSU}

Fresh leaf tissue was ground in liquid nitrogen and $0.5 \mathrm{~g}$ of powder was used for extraction. Soluble and membrane proteins were extracted by adding solution containing $0.013 \mathrm{M}$ Tris $\mathrm{pH}=8,4.6 \%$ SDS, $1.54 \%$ DTT and $15 \%$ glycerol pre-warmed at $80{ }^{\circ} \mathrm{C}$. After $10 \mathrm{~min}$ utes of extraction at $80{ }^{\circ} \mathrm{C}$, samples were centrifuged at $+4{ }^{\circ} \mathrm{C}$ for 10 minutes at $18000 \mathrm{~g}$. The concentration of total protein content was determined spectrophotometrically according to BRADFORD (1976) using bovine serum albumin (BSA) as a standard. Aliquots containing $30 \mu \mathrm{g}$ proteins per lane were mixed with Laemmli sample buffer $(0.065 \mathrm{M}$ Tris-HCl buffer containing $6 \%$ SDS, $6 \% \beta$-mercaptoethanol, 30\% glycerol and $0.01 \%$ bromphenol blue), boiled for 5 minutes and loaded on the gel. The samples were separated by SDSPAGE (Mini-gel Twin, Biometra, Germany) using 12\% polyacrylamide gels and blotted onto a nitrocellulose membrane (Fastblot B43, Biometra, Germany). The membranes were blocked with 5\% non-fat powdered milk solution in PBS buffer $\left(58 \mathrm{mM} \mathrm{Na}_{2} \mathrm{HPO}_{4}, 17 \mathrm{mM}\right.$ $\mathrm{NaH}_{2} \mathrm{PO}_{4}, 68 \mathrm{mM} \mathrm{NaCl}$ ) $\mathrm{pH}=7.4$ containing $1 \%$ Tween 20 over night at $4{ }^{\circ} \mathrm{C}$ and incubated with rabbit monoclonal antibodies raised against the pea Rubisco LSU, D1, LHCII and cytochrome $f$ for 2 hours at room temperature. After washing, membranes were probed with an anti-rabbit alkaline - phosphatase conjugated secondary IgG antibody diluted 1:30 000 in PBST. Protein bands were visualized using BCIP/NBT (5-bromo-4-chloro3-indolyl phosphate and nitroblue tetrazolium and images were analyzed using Kodak 1D 3.6 software (LEPEDUŠ et al. 2005, 2008).

\section{Measurement of chlorophyll $a$ fluorescence}

In vivo chlorophyll $a$ fluorescence measurements were performed using a pulse-amplitude-modulated photosynthesis yield analyser (Mini-PAM, Waltz). The plant material (10 leaves $(\mathrm{n}=10)$ taken from 5 different trees) was dark-adapted for approximately 30 minutes before measurement. Minimal $\left(F_{0}\right)$ and maximal $\left(F_{m}\right)$ fluorescence yields were measured in the dark-adapted leaves. The same parameters $(F)$ and $\left(F^{\prime}{ }_{m}\right)$ were measured upon light applications (photosynthetic photon flux density (PPFD) of 100, 500 and $1100 \mu \mathrm{mol} \mathrm{m} \mathrm{m}^{-2} \mathrm{~s}^{-1}$ ). The radiation was maintained until both, $F$ and $F^{\prime} m$ were stable. The maximum quantum yield of the photosystem II $\left(F_{v} / F_{m}\right)$ as well as the effective quantum yield of the photosystem II $\left(\Delta F / F^{\prime} m\right)$ were calculated according to SCHREIBER et al. (1994). 
Lepeduš H., Begović L., Mlinarić S., Šimić D., Štolfa I., PARAĐiković N. et al.

The chlorophyll $a$ fluorescence transient measurement (OJIP test) was performed with the use of a Plant Efficiency Analyser (PEA, Hansatech). Plant material (25 leaves $(n=25)$ taken from 5 different trees) was dark-adapted for about 30 minutes before measurements. Chlorophyll fluorescence transients were induced by applying the pulse of saturating red light (peak at $650 \mathrm{~nm}, 3000 \mu \mathrm{mol} \mathrm{m} \mathrm{m}^{-2} \mathrm{~s}^{-1}$ ). Changes in fluorescence were measured for $1 \mathrm{~s}$, starting from $50 \mu \mathrm{s}$ after onset of illumination. During the first $2 \mathrm{~ms}$ changes were recorded every $10 \mu \mathrm{s}$ and every $1 \mathrm{~ms}$ afterward. The obtained data were used in OJIP test (Strasser et al. 2004) in order to calculate several parameters of PSII photochemistry (Tab. 1).

Tab. 1. OJIP test parameters and expressions.

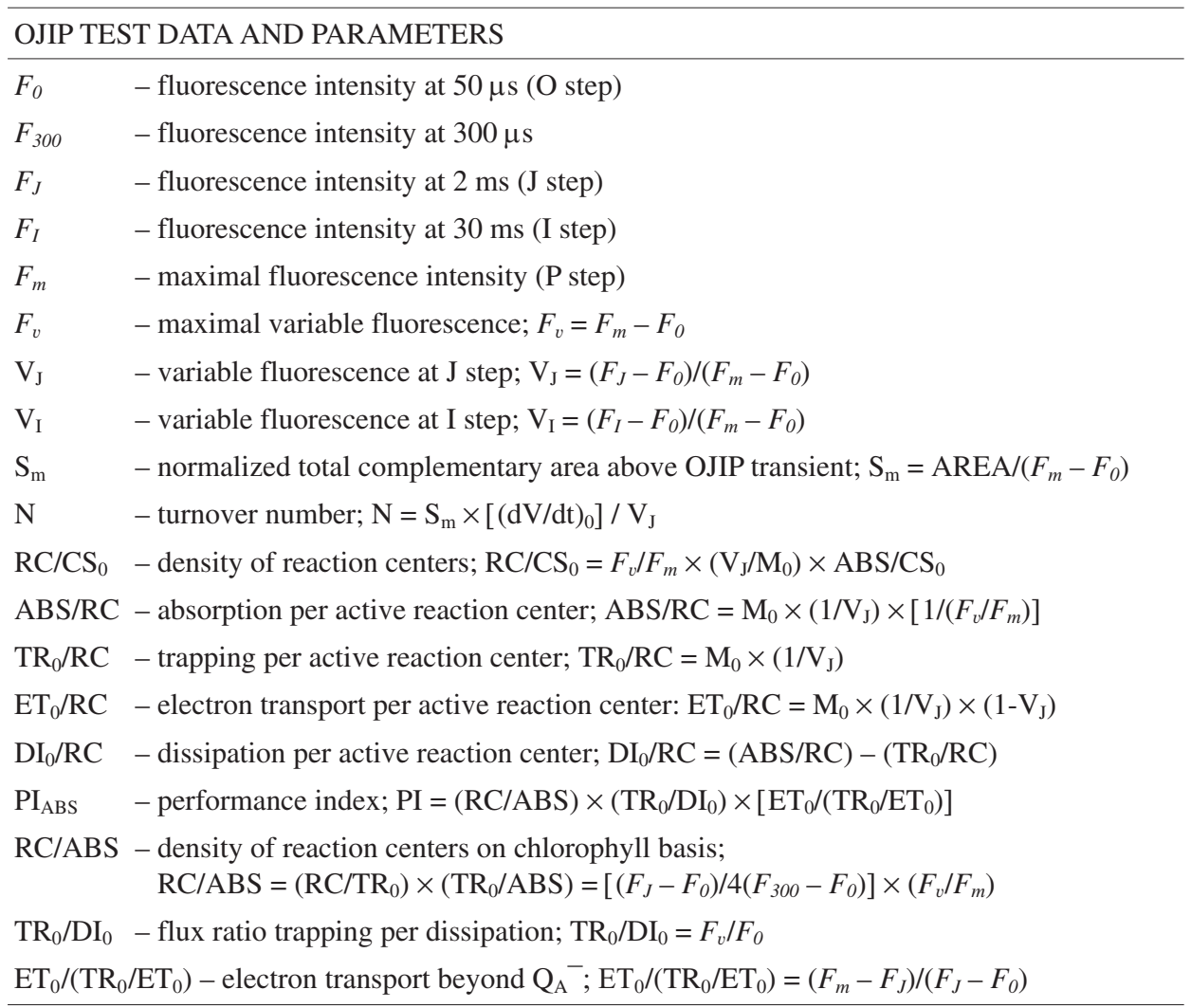

\section{Oxygen evolution}

Oxygen evolution was measured using the gas-phase Clark-type oxygen electrode (Hansatech). Five bleached and five green leaves were analyzed, each taken from a different tree. The leaf discs $\left(2.5 \mathrm{~cm}^{2}\right)$ were placed in the reaction chamber and the oxygen evolution was measured at three different light levels 100,500 and $1100 \mu \mathrm{mol} \mathrm{m}^{-2} \mathrm{~s}^{-1}$. The temperature inside the reaction chamber was $25^{\circ} \mathrm{C}$. 


\section{Inductively-coupled plasma optical emission spectroscopy (ICP-OES) analysis for mineral concentrations in leaves}

For determination of mineral concentration content combined samples of 3 replicates for every leaf type were used. Leaves were dried at $105^{\circ} \mathrm{C}$ for 72 hours and ground into a powder. Mineral concentrations in leaves were determined by inductively-coupled plasma optical emission spectroscopy (ICP-OES) after microwave digestion. Leaves were digested in $65 \%$ nitric acid $\left(\mathrm{HNO}_{3}\right)+30 \%$ hydrogen-peroxide $\left(\mathrm{H}_{2} \mathrm{O}_{2}\right)$ with a Milestone MLS 1200 microwave (ZARCINAS et al. 1987). The analyses were performed with a Jobin-Yvon Ultrace 238 ICP-OES spectrometer.

\section{Statistical analysis}

Data on Chl $a+b$, PChl, elemental analysis and OJIP parameters were analyzed by t-test. Data on the maximum quantum yield of the photosystem II $\left(F_{v} / F_{m}\right)$, effective quantum yield of the photosystem II $\left(\Delta F / F^{\prime}{ }_{m}\right)$ and oxygen evolution were analyzed by one-way analysis of variance (ANOVA) and Fischer LSD (Least significant difference) for post hoc analysis. Differences were considered significant at $\mathrm{p} \leq 0.05$. All statistical analyses were done with Statistica 7.1. Software (StatSoft, Inc. 2005).

\section{Results}

Total chlorophyll (Chl $a+b)$ concentration, protochlorophyllide (PChl) concentration and total chlorophyll to protochlorophyllide ratio in green leaves were significantly higher $(72 \%)$ than in bleached leaves (Tab. 2).

Tab. 2. Mean values ( \pm standard deviation) of total chlorophyll (Chl $a+b)$ concentration, protochlorophyllide (PChl) concentration and total chlorophylls to protochlorophyllide ratio in green $(\mathrm{G})$ and bleached $(\mathrm{B})$ leaves of silver maple (Acer saccharinum). $\mathrm{P}(\mathrm{t})$ - percent of similarity.

\begin{tabular}{lcccc}
\hline Parameters & $\mathrm{G}$ & $\mathrm{B}$ & $\mathrm{t}$ & $\mathrm{P}(\mathrm{t})$ \\
\hline Chl $a+b\left(\mathrm{mg} \mathrm{g}^{-1} \mathrm{FM}\right)$ & $2.57 \pm 0.09$ & $0.72 \pm 0.05$ & 60.514 & $<0.1 \%$ \\
PChl $\left(\mathrm{mg} \mathrm{g}^{-1} \mathrm{FM}\right)$ & $0.33 \pm 0.06$ & $0.19 \pm 0.03$ & 6.502 & $<0.1 \%$ \\
Chl $a+b /$ PChl & $8.07 \pm 1.71$ & $3.84 \pm 0.31$ & 7.696 & $<0.1 \%$ \\
\hline
\end{tabular}

Bleached leaves had lower $\mathrm{Al}, \mathrm{Cr}, \mathrm{Cu}, \mathrm{Fe}, \mathrm{K}, \mathrm{Zn}$ and higher $\mathrm{S}$ concentrations than green leaves (Tab. 3).

In comparison to green, bleached leaves had 34.6, 35.7, 38 and $27.7 \%$ reduced abundances of D1, LHCII, cytochrome $f$ and Rubisco LSU, respectively (Fig. 1).

Down-regulation of PSII photochemical efficiency was found (Fig. 2A). Maximum quantum yield of PSII $\left(F_{v} / F_{m}\right)$ was 0.81 in green leaves and 0.72 in bleached leaves. Effective quantum yields of PSII $\left(\Delta F / F_{m}{ }_{m}\right)$ were also decreased in bleached leaves. The values of $\Delta F / F^{\prime}{ }_{m}$ at PPFD of $100,500,1000 \mu \mathrm{mol} \mathrm{m}{ }^{-2} \mathrm{~s}^{-1}$ were $0.72,0.52$ and 0.37 , respectively, in green leaves. In bleached leaves the values of $\Delta F / F^{\prime}{ }_{m}$ at the same light intensities were 
Lepeduš H., Begović L., Mlinarić S., Šimić D., Štolfa I., PARAĐiković N. et al.

Tab. 3. Mean values ( \pm standard deviation) of element concentrations (mg kg-1 dry mass) in green (G) and bleached (B) leaves of silver maple (Acer saccharinum). P(t) - percent of similarity, NS not significant.

\begin{tabular}{|c|c|c|c|c|}
\hline Elements & G & $\mathrm{B}$ & $\mathrm{t}$ & $\mathrm{P}(\mathrm{t})$ \\
\hline $\mathrm{Al}$ & $70.97 \pm 0.68$ & $45.67 \pm 2.94$ & 11.390 & $<5 \%$ \\
\hline B & $117.19 \pm 8.32$ & $10.78 \pm 3.29$ & 3.068 & NS \\
\hline $\mathrm{Ba}$ & $2.70 \pm 0.51$ & $2.70 \pm 0.04$ & 2.393 & NS \\
\hline $\mathrm{Ca}$ & $10617.46 \pm 676.84$ & $10617.46 \pm 96.18$ & 6.594 & NS \\
\hline $\mathrm{Cr}$ & $1.88 \pm 0.30$ & $0.50 \pm 0.03$ & 8.549 & $<5 \%$ \\
\hline $\mathrm{Cu}$ & $12.21 \pm 0.32$ & $5.61 \pm 0.05$ & 37.933 & $<5 \%$ \\
\hline $\mathrm{Fe}$ & $116.77 \pm 4.71$ & $57.99 \pm 2.17$ & 19.835 & $<5 \%$ \\
\hline K & $11187.92 \pm 895.99$ & $14770.64 \pm 88.62$ & 7.514 & $<5 \%$ \\
\hline $\mathrm{Mg}$ & $3783.79 \pm 95.05$ & $3889.90 \pm 60.19$ & 1.578 & NS \\
\hline $\mathrm{Mn}$ & $33.55 \pm 1.58$ & $27.59 \pm 0.16$ & 7.082 & NS \\
\hline Mo & $0.19 \pm 0.07$ & $0.18 \pm 0.01$ & 0.323 & NS \\
\hline $\mathrm{Na}$ & $11.81 \pm 4.10$ & $7.97 \pm 1.47$ & 1.585 & NS \\
\hline ONi & $0.85 \pm 0.32$ & $0.32 \pm 0.09$ & 2.859 & NS \\
\hline $\mathrm{P}$ & $3574.91 \pm 214.73$ & $3255.21 \pm 52.24$ & 2.671 & NS \\
\hline $\mathrm{Sr}$ & $8.42 \pm 1.19$ & $8.96 \pm 0.09$ & 0.856 & NS \\
\hline $\mathrm{Zn}$ & $36.44 \pm 0.22$ & $21.01 \pm 0.35$ & 54.242 & $<5 \%$ \\
\hline $\mathrm{S}$ & $2131.34 \pm 55.53$ & $2419.62 \pm 26.37$ & 8.178 & $<5 \%$ \\
\hline
\end{tabular}

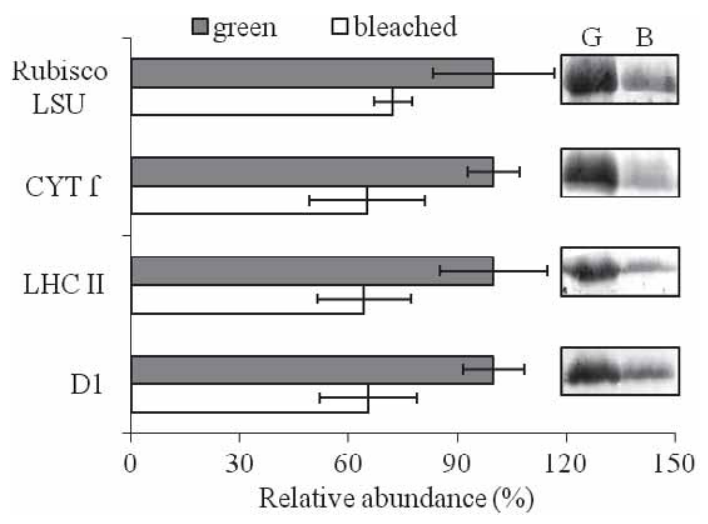

Fig. 1. Relative abundance of D1, Rubisco LSU, cytochrome $f$ and LHCII proteins on imunoblots in green $(\mathrm{G})$ and bleached (B) leaves of silver maple (Acer saccharinum $\mathrm{L}$.). The abundance of each protein in $\mathrm{G}$ leaves was taken as $100 \%$. Horizontal bars indicate relative standard deviation.

$0.59,0.35$ and 0.24 , respectively. Relative electron transport rates (rel. ETR), shown in figure $2 \mathrm{~B}$, at higher light intensities were lower in bleached than in green leaves. At 100, 500, $1000 \mu \mathrm{mol} \mathrm{m}{ }^{-2} \mathrm{~s}^{-1}$ measured relative electron transport rates were $35.86,130.80$ and 202.62 

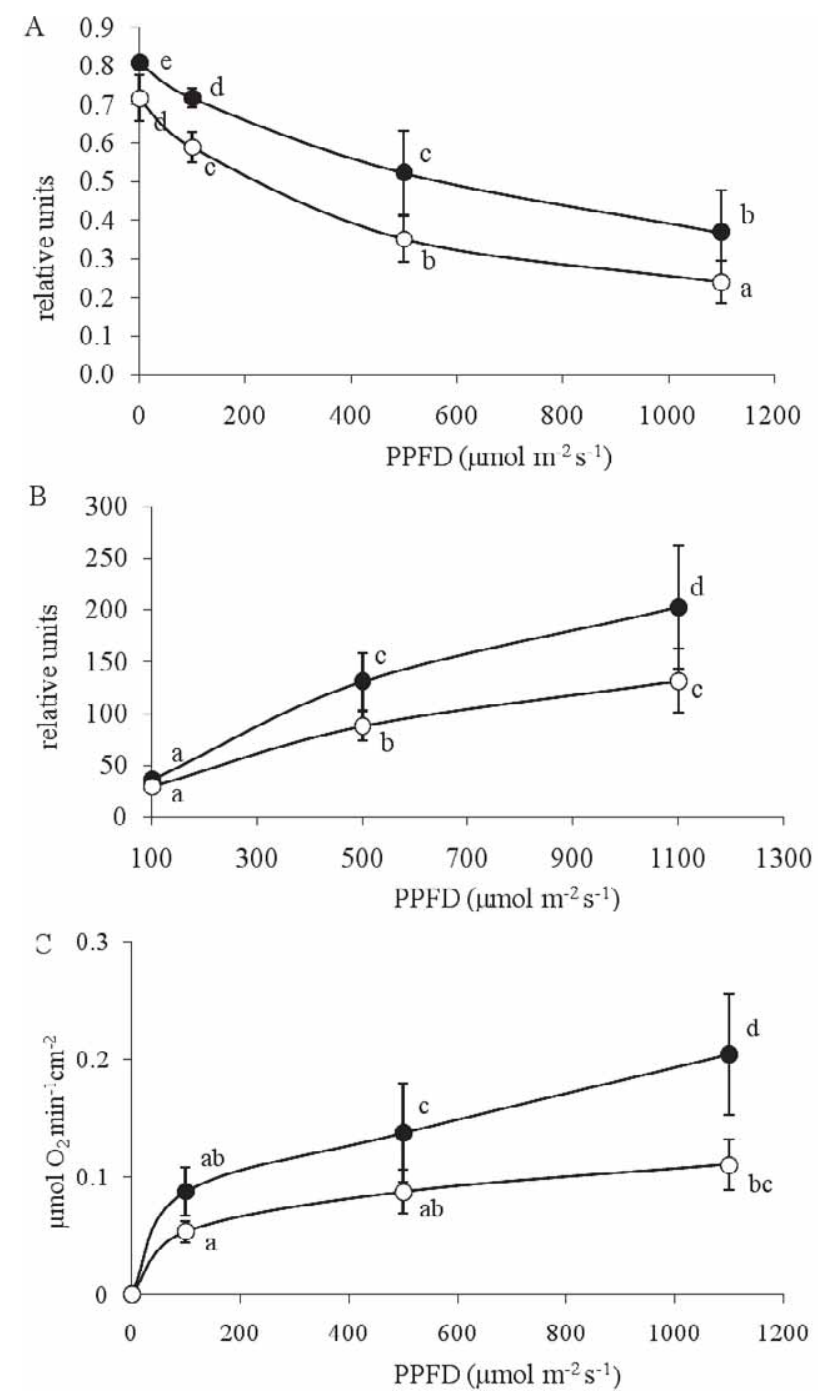

Fig. 2. The arithmetic mean values and standard deviations of photosystem II efficiency (given as maximum quantum yield $\left(F_{v} / F_{m}\right)$ at 0 PPFD and effective quantum yields $\left(\Delta F / F_{m}^{\prime}\right)(\mathrm{A})$, relative electron-transport rate (rel. ETR) (B) and PSII capacity for oxygen evolution (C) in green (grey circles) and bleached (white circles) leaves of silver maple (Acer saccharinum L.). Significant differences between G, YG and Y leaves were designated by different letters $(\mathrm{a}, \mathrm{b}, \mathrm{c})$ placed near the circles.

PPFD (in $\mu \mathrm{mol} \mathrm{m} \mathrm{m}^{-2} \mathrm{~s}^{-1}$ ) - photosynthetically active photon flux density; vertical bars indicate standard deviation.

in green leaves, respectively while measured relative electron transport rates in bleached leaves were $29.53,87.95$ and 131.96 , respectively. In figure $2 \mathrm{C}$ capacity for oxygen production is shown. At PPFD of 500 and $1100 \mu \mathrm{mol} \mathrm{m} \mathrm{m}^{-2} \mathrm{~s}^{-1}$ it was lower in bleached than in green leaves, while no difference was observed at low light level $\left(100 \mu \mathrm{mol} \mathrm{m}^{-2} \mathrm{~s}^{-1}\right)$ 
The chlorophyll $a$ fluorescence transient, revealed a usual OJIP curve shape in both leaf types (Fig. 3A). O-P normalized curves revealed the increase of fluorescence in $\mathrm{J}$ and I steps in bleached leaves (Fig. 3B).
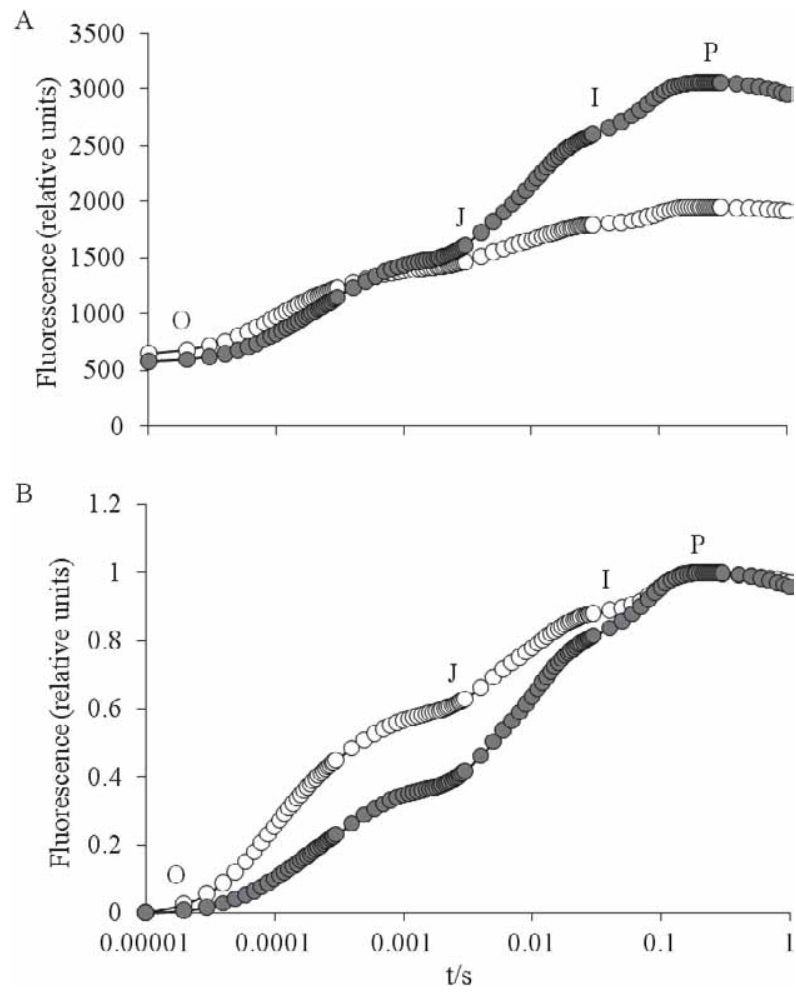

Fig. 3. OJIP chlorophyll $a$ fluorescence transients without normalization (A) and O-P normalized (B) in green (grey circles) and bleached (white circles) leaves of silver maple (Acer saccharinum $\mathrm{L}$ ).

Chlorophyll $a$ fluorescence parameters revealed that the $F_{0}$ value corresponded in green and bleached leaves, but maximal fluorescence intensity, $F_{m}$ values were lower in bleached leaves (Tab. 4). Also, the turnover number $(\mathrm{N}), \mathrm{S}_{\mathrm{m}}$ value and density of active reaction centres $\left(\mathrm{RC} / \mathrm{CS}_{0}\right)$ significantly decreased in bleached leaves.

Specific fluxes or specific activities per active reaction centre were calculated (Tab. 5) to show functioning of PSII reaction centres. Parameters describing absorption (ABS/RC) and trapping $\left(\mathrm{TR}_{0} / \mathrm{RC}\right)$ of light energy per active reaction centre were higher in bleached leaves than in green leaves, as was dissipation of excess energy $\left(\mathrm{DI}_{0} / \mathrm{RC}\right)$. The capability of bleached leaves for electron transport beyond $\mathrm{Q}_{\mathrm{A}}-\left(\mathrm{ET}_{0} / \mathrm{RC}\right)$ was significantly lower.

Values of performance index $\left(\mathrm{PI}_{\mathrm{ABS}}\right)$ and its components in green and bleached leaves revealed that green leaves had higher $\mathrm{PI}_{\mathrm{ABS}}$, as well as density of reaction centres on chlorophyll basis (RC/ABS), ratio of trapping and dissipation fluxes $\left(\mathrm{TR}_{0} / \mathrm{DI}_{0}\right)$ and efficiency of the conversion of excitation energy to electron transport $\left(\mathrm{ET}_{0} /\left(\mathrm{TR}_{0}-\mathrm{ET}_{0}\right)\right.$ (Tab. 6). 
Tab. 4. The mean values ( \pm standard deviation) of chlorophyll $a$ fluorescence parameters in green (G) and bleached (B) leaves of silver maple (Acer saccharinum). All parameters are expressed in relative units. $\mathrm{P}(\mathrm{t})$ - percent of similarity, NS - not significant.

\begin{tabular}{lcccc}
\hline Parameters & $\mathrm{G}$ & $\mathrm{B}$ & $\mathrm{t}$ & $\mathrm{P}(\mathrm{t})$ \\
\hline$F_{0}$ & $565.36 \pm 92.09$ & $650.92 \pm 206.35$ & 12.940 & $\mathrm{NS}$ \\
$F_{m}$ & $3133.56 \pm 308.72$ & $1908.12 \pm 359.03$ & 1.893 & $<0.1 \%$ \\
$\mathrm{Vj}$ & $0.383 \pm 0.02$ & $0.588 \pm 0.05$ & 17.896 & $<0.1 \%$ \\
$\mathrm{Vi}$ & $0.820 \pm 0.03$ & $0.883 \pm 0.03$ & 7.322 & $<0.1 \%$ \\
$\mathrm{Sm}$ & $17.82 \pm 2.99$ & $12.45 \pm 2.59$ & 6.785 & $<0.1 \%$ \\
$\mathrm{~N}$ & $44,09 \pm 5.61$ & $37,06 \pm 7.78$ & 3.662 & $<1 \%$ \\
$\mathrm{RC} / \mathrm{CS}_{0}$ & $184.95 \pm 18.45$ & $141.57 \pm 36.43$ & 5.312 & $<0.1 \%$ \\
\hline
\end{tabular}

Tab. 5. The mean values ( \pm standard deviation) of specific fluxes or specific activities per active reaction centre in green $(\mathrm{G})$ and bleached (B) leaves of silver maple (Acer saccharinum). All parameters are expressed in relative units. $\mathrm{P}(\mathrm{t})$ - percent of similarity.

\begin{tabular}{lcccc}
\hline Parameters & $\mathrm{G}$ & $\mathrm{B}$ & $\mathrm{t}$ & $\mathrm{P}(\mathrm{t})$ \\
\hline $\mathrm{ABS} / \mathrm{RC}$ & $3.044 \pm 0.24$ & $4.558 \pm 0.54$ & 12.870 & $<0.1 \%$ \\
$\mathrm{TR}_{0} / \mathrm{RC}$ & $2.493 \pm 0.16$ & $2.981 \pm 0.16$ & 11.574 & $<0.1 \%$ \\
$\mathrm{ET}_{0} / \mathrm{RC}$ & $1.539 \pm 0.10$ & $1.228 \pm 0.16$ & 8.173 & $<0.1 \%$ \\
$\mathrm{DI}_{0} / \mathrm{RC}$ & $0.550 \pm 0.09$ & $1.577 \pm 0.52$ & 9.788 & $<0.1 \%$ \\
\hline
\end{tabular}

Tab. 6. The mean values ( \pm standard deviation) of performance index (PIABS) and its components in green $(\mathrm{G})$ and bleached (B) leaves of silver maple (Acer saccharinum). All parameters are expressed in relative units. $\mathrm{P}(\mathrm{t})$ - percent of similarity.

\begin{tabular}{lcccc}
\hline Parameters & $\mathrm{G}$ & $\mathrm{B}$ & $\mathrm{t}$ & $\mathrm{P}(\mathrm{t})$ \\
\hline $\mathrm{PI}_{\mathrm{ABS}}$ & $2.475 \pm 0.44$ & $0.324 \pm 0.11$ & 23.812 & $<0.1 \%$ \\
$\mathrm{RC} / \mathrm{ABS}$ & $0.330 \pm 0.03$ & $0.222 \pm 0.02$ & 15.475 & $<0.1 \%$ \\
$\mathrm{TR}_{0} / \mathrm{DI}_{0}$ & $4.602 \pm 0.48$ & $2.064 \pm 0.58$ & 17.085 & $<0.1 \%$ \\
$\mathrm{ET}_{0} /\left(\mathrm{TR}_{0}-\mathrm{ET}_{0}\right)$ & $1.619 \pm 0.12$ & $0.716 \pm 0.16$ & 22.687 & $<0.1 \%$ \\
\hline
\end{tabular}

\section{Discussion}

Numbers of reports have revealed that changes in chlorophylls content and photosynthetic performance can be considered as very sensitive indicators for different biotic and abiotic stresses as well as developmental processes in higher plants (MuNNE-BosCH 2008, TAKAhashi and Murata 2008, ĆurKoviĆ-PeriCA et al. 2007, Fulgosi et al. 2005, LePEDUŠ et al. 2005, PFANNSCHMIDT 2003, MiTTLER 2002). Bleaching is often caused by disturbance in mineral nutrition. Our investigation of maple leaf premature aging (UŽAREVIĆ et al. 2011) 
revealed increased levels of organic nitrogen (for 19.85\%) and soluble proteins (for $208.05 \%$ ). In this study we analyzed the abundance of some other elements in leaves (Tab. 3). Differences in elemental concentrations were found between green and bleached leaves. Bleached leaves had decreased $\mathrm{Al}, \mathrm{Cr}, \mathrm{Cu}, \mathrm{Fe}, \mathrm{K}, \mathrm{Zn}$ and increased $\mathrm{S}$ concentrations in comparison to healthy green leaves. It can be speculated that increased $\mathrm{S}$ content might account for the increase in the synthesis of glutathione (MENDOZA-CózATL et al. 2005, RAUSCH and WACHTER 2005) and in this way enhance the protection against potential oxidative damage. Surprisingly, Mg and Mn content did not differ between green and bleached leaves, indicated that the bleaching symptom was not due to any deficiency of these elements. Chlorophyll degradation is an enzymatically regulated process (RoDONI et al. 1998, 1997, MATILE et al. 1996,) accompanied by breakdown of pigment-protein complexes in photosynthetic membranes (TANG et al. 2005). The concentration of protochlorophyllide, a precursor in chlorophyll biosynthesis (SUZUKI et al. 1997), was decreased in bleached leaves to $57 \%$ of that in green leaves. The decreased total chlorophyll to protochlorophyllide ratio in bleached leaves indicated that lowering of total chlorophyll content was not brought about merely by degradation but also due to decreased biosynthetic capability of bleached leaves. Chlorophyll biosynthesis is to a large degree dependent on iron, which was shown to be deficient in bleached leaves (Tab. 3). Iron is known to be a co-factor of many enzymes of the chlorophyll biosynthetic pathway and also an important part of the electron-transport chain in chloroplasts. A deficiency is usually accompanied by bleaching symptoms and decrease in photosynthetic performance (ITURBE-ORMAEXTE et al. 1995). Decreased photosynthesis was due not only to decreased pigments content but also to changes in chloroplast proteome (BRIAT et al. 2007). Relative abundance of major photosynthetic proteins investigated here (Fig. 1) showed that in comparison to green leaves, bleached leaves had 34.6, 35.7, 38 and $27.7 \%$ reduced abundances of D1, LHCII, cytochrome $f$ and Rubisco LSU, respectively. ANDALUZ et al. (2006) reported reduced abundance of chloroplast electron-transport proteins and an increased amount of carbon assimilation proteins, in response to Fe deficiency. Since our results revealed that the abundance of Rubisco LSU was also decreased in bleached leaves (Fig. 1) it can be speculated that premature bleaching of the investigated maple leaves was influenced not by Fe deficiency alone, rather, in combination with some other ecological and/or physiological factors such as high light, drought and elevated temperatures. This also implies that the observed bleaching is most likely a pleiotropic effect influenced by many cellular energetic and metabolic processes.

In this study down-regulation of PSII photochemical efficiency was shown (Fig. 2A). Maximum quantum yield of PSII $\left(F_{v} / F_{m}\right)$ in bleached leaves $(0.72)$ was significantly decreased in comparison to green leaves $(0.81)$. Since the value of 0.75 for $F_{v} / F_{m}$ has been considered to be a boundary value for fully functional PSII (BOLHÀr-NORDENKAMPF et al. 1989) the values measured in bleached leaves indicated impaired PSII photochemistry. Effective quantum yields of PSII $\left(\Delta F / F_{m}\right)$ were also significantly decreased in bleached leaves (Fig. 2A). Since $\Delta F / F_{m}$ corresponds to the proportion of the light absorbed by chlorophylls associated with PSII (MAXWELL and JOHNSON 2000), decrease in $\Delta F / F{ }_{m}$ (Fig. 2A) was in accordance with the observed chlorophylls content decrease (Tab. 2) in bleached leaves. Down-regulation of $\Delta F / F_{m}{ }_{m}$ in bleached leaves is reflected in PSII-driven electron transport (Fig. 2B). Decrease in relative electron transport rates (rel. ETR) at higher light intensities might be related to a reduced abundance of Rubisco enzyme, since a 
clear relationship between $\mathrm{CO}_{2}$ fixation and PSII driven electron transport was established (KRALL et al. 1992). In addition to marked down-regulation of photochemical efficiency, reduced capacity for oxygen production at 500 and $1100 \mu \mathrm{mol} \mathrm{m}^{-2} \mathrm{~s}^{-1}$ was also found in bleached leaves (Fig. 2C). Oxygen is produced as the by-product of photosynthesis during water oxidation at oxygen evolving complex (OEC) which is constitutive part of PSII (IWATA and BARBER 2004, RAYMOND and BLANKENSHIP 2008). It has been postulated that $S$ state of OEC plays an important role in chlorophyll fluorescence rise at J-step of OJIP curve (STRASSER et al. 2004). The chlorophyll $a$ fluorescence transient revealed usual OJIP curve shape in both leaf types (Fig. 3A). The $F_{0}$ did not differ between green and bleached leaves, but $F_{m}$ values appeared to be much lower in bleached leaves (Tab. 4). Since $F_{m}$ is obtained when all $\mathrm{Q}_{\mathrm{A}}$ molecules are reduced (SCHREIBER et al. 1994), changes in $F_{m}$ level usually reflect heat dissipation events in PSII (MAXWELL and JOHNSON 2000). O-P normalized curves revealed the increase of fluorescence in $\mathrm{J}$ and I steps (Fig. 3B). Rise in the $\mathrm{O}-\mathrm{J}$ step in bleached leaves, seen as an increase in variable fluorescence at $2 \mathrm{~ms}\left(\mathrm{~V}_{\mathrm{J}}\right)$, can be explained by the accumulation of reduced primary plastoquinone $\left(\mathrm{Q}_{\mathrm{A}}^{-}\right)$because of their inability to transfer electrons efficiently further than $\mathrm{Q}_{\mathrm{A}}{ }^{-}$. Parameters that describe the accumulation of $\mathrm{Q}_{\mathrm{A}}{ }^{-}$very well are the turnover number $(\mathrm{N})$ representing the number of $\mathrm{Q}_{\mathrm{A}}$ reduction events between $F_{0}$ and $F_{m}$ and normalized total complementary area above OIJP transient $\left(\mathrm{S}_{\mathrm{m}}\right)$, which corresponds to the energy needed to close all reaction centres (STRASSER et al. 2000). Both parameters were significantly lower in bleached (Tab. 4) than in green leaves, indicating the reduced transport from $\mathrm{Q}_{\mathrm{A}}{ }^{-}$to $\mathrm{Q}_{\mathrm{B}}$. Also, there was a rise in the $\mathrm{J}$ - I step that was evident as increase in variable fluorescence at $30 \mathrm{~ms}$ (VI) (Tab. 3). While the $\mathrm{O}-\mathrm{J}$ step represents the full reduction of $\mathrm{Q}_{\mathrm{A}}$ (photochemical phase), the $\mathrm{J}-\mathrm{I}-\mathrm{P}$ steps represent thermal phases associated with reduction of secondary plastoquinone (non-photochemical phase) (STRASSER et al. 1995). The latest steps reflect the PSII heterogeneity due to the presence of fast and slow reducing plastoquinone (PQ) reaction centres (STIRBET et al 1998). In order to analyze the functioning of PSII reaction centres specific fluxes or specific activities per active reaction centre were calculated (Tab. 5). Parameters describing absorption $(\mathrm{ABS} / \mathrm{RC})$ and trapping $\left(\mathrm{TR}_{0} / \mathrm{RC}\right)$ of light energy per active $\left(\mathrm{Q}_{\mathrm{A}}\right.$ reducing) reaction centre were higher in bleached leaves than in green leaves. The increase in average functional antenna size (ABS/RC) (Tab. 5) together with decreased density of active reaction centres $\left(\mathrm{RC} / \mathrm{CS}_{0}\right)$ (Tab. 4$)$ indicate the presence of non- $\mathrm{Q}_{\mathrm{A}}$ reducing reaction centres in bleached leaves. Such non- $\mathrm{Q}_{\mathrm{A}}$ reducing reaction centres are also called silent reaction centres and act as heat sinks (STRASSER et al. 2004). According to STRASSER et al. (2004) the fraction of remained active reaction centres in bleached leaves might be calculated using the expression: $\mathrm{RC}_{\text {control (green) }} / \mathrm{RC}_{\text {stressed (bleached) }}=(\mathrm{ABS} / \mathrm{RC})_{\text {stressed (bleached) }} /(\mathrm{ABS} / \mathrm{RC})_{\text {control (green) }}$ and it was $66.78 \%$ of that in green leaves. Further, the capability of bleached leaves for electron transport beyond $\mathrm{Q}_{\mathrm{A}}{ }^{-}\left(\mathrm{ET}_{0} / \mathrm{RC}\right)$ was significantly impaired (Tab. 5) due to reduced transport from $\mathrm{Q}_{\mathrm{A}}{ }^{-}$to $\mathrm{QB}$. This resulted in an about three-fold increased dissipation of excess energy $\left(\mathrm{DI}_{0} / \mathrm{RC}\right)$ (Tab. 5) in order to avoid oxidative damage of PSII. Described differences in the shape of chlorophyll $a$ fluorescence transient curves (Fig. 3) between green and bleached leaves were reflected on values of performance index (PIABS) (Tab. 6). This parameter was established by STRASSER et al. (2000) and describes overall photosynthetic performance. It combines several parameters that describe three main functional characteristics of PSII reaction centre, namely RC/ABS (density of reaction centres on chlorophyll basis), $\mathrm{TR}_{0} / \mathrm{DI}_{0}$ (ratio of trapping and dissipation fluxes) and $\mathrm{ET}_{0} /\left(\mathrm{TR}_{0}-\mathrm{ET}_{0}\right.$ ) (efficiency of the 
conversion of excitation energy to electron transport). Green leaves had about two-fold higher $\mathrm{PI}_{\mathrm{ABS}}$ than bleached, with all of its components decreased in bleached leaves (Tab. 6).

From the presented results, it can be concluded that maple leaves of lower vitality revealed bleaching caused by disturbed mineral nutrition with marked Fe deficiency but with $\mathrm{Mg}$ and $\mathrm{Mn}$ content comparable with green healthy leaves. Data on the photosynthesis performance and biochemistry indicated that bleaching was not a simple symptom of premature aging but rather an adaptation to high-light induced oxidative stress during summer. In that manner, down-regulation of total chlorophylls and major photosynthetic proteins content (D1, LHCII, cytochrome $f$ and Rubisco LSU) occurred. These biochemical processes were accompanied with marked changes in PSII photochemistry. The most important feature of PSII was the down-regulation of its efficiency, which was achieved by modifications of a certain fraction of RCs, turning them from active to dissipative. Such dissipative $\mathrm{RCs}$ were characterised by the presence of non- $\mathrm{Q}_{\mathrm{A}}$ and non- $\mathrm{Q}_{\mathrm{B}}$ reducing $\mathrm{RCs}$ which resulted by in reduced overall photosynthetic performance, seen as decrease in oxygen evolution and $\mathrm{PI}_{\mathrm{ABS}}$ value.

\section{Acknowledgments}

This work was supported by the scientific research grants to H. L. (research agreement 073-0731674-1673), V.C. (research agreement 073-0731674-0841) and D.Š. (research agreement 073-0730463-0203), all funded by the Ministry of Science, Education and Sports of the Republic of Croatia.

\section{References}

Andaluz, S., López-Milán, A. F., De las Rivas, J., Aro, E. M., Abaída, J., Abaide, A., 2006: Proteomic profiles of thylakoid membranes and changes in response to iron deficiency. Photosynthesis Research 89, 141-155.

Barber, J., Nield, J., Morris, E.P., Zheleva, D., Hankamer, B., 1997: The structure, function and dynamics of photosystem two. Physiologia Plantarum 100, 817-827.

Bolhàr-Nordenkampf, H. R., Long, S. P., Baker, N. R., Öuquist, G., Schreiber, U., LECHNER, E. G., 1989: Chlorophyll fluorescence as a probe of the photosynthetic competence of leaves in the field: A Review of Current Instrumentation. Functional Ecology $3,497-514$.

BRADFORD, M. M., 1976: A rapid and sensitive method for the quantitation of microgram quantities of protein utilizing the principle of protein-dye binding. Analytical Biochemistry $72,248-254$.

Briat, J. F., Curie, C., Gaymard, F., 2007: Iron utilization and metabolism in plants. Current Opinion in Plant Biology 10, 276-282.

Ćurković-PericA, M., LePeduš, H., ŠERUGa Musić, M., 2007: Effect of indole-3-butyric acid on phytoplasmas in infected Catharanthus roseus shoots grown in vitro. FEMS Microbiology Letters 268, 171-177. 
Day, S. D., Seiler, J. R., Persaud, N., 2000: A comparison of root growth dynamics of silver maple and flowering dogwood in compacted soil at differing soil water contents. Tree Physiology 20, 257-263.

Fulgosi, H., LePeduš, H., CesAR, V., LuUbešić, N., 2005: Differential accumulation of plastid preprotein translocon components during spruce (Picea abies L. Karst.) needle development. Biological Chemistry 368, 777-783.

Hardin, J. W., Leopold, D. J., White, F. M., 2001: Harlow and Harrar's textbook of dendrology, 443-459. McGraw-Hill, New York.

Houston, D. R., 1999: History of sugar maple decline. U.S. Department of Agriculture, Forest Service, Northeastern Research Station, Technical Report NE-261, 19-26.

Iturbe-Ormaexte, I., Moran, J. F., Arrese-Igor, C., Gogorcena, Y., Klucas, R. V., BeCANA, M., 1995: Activated oxygen and antioxidant defences in iron-deficient pea plants. Plant Cell and Environment 18, 421-429.

IwATA, S., BARBER, J., 2004: Structure of photosystem II and molecular architecture of the oxygen-evolving centre. Current Opinion in Structural Biology 14, 447-453.

Jing, H., Hille, J., DiJkwel, R., 2003: Ageing in plants: Conserved strategies and novel pathways. Plant Biology 5, 455-464.

Krall, J. P., EDWARDS, G. E., 1992: Relationship between photosystem II activity and $\mathrm{CO}_{2}$ fixation in leaves. Physiologia Plantarum 86, 180-187.

LePeduš, H., Schlensog, M., Müller, L., KRuPINSKA, K., 2005: Function and molecular organisation of photosystem II in vegetative buds and mature needles of Norway spruce during the dormancy. Biologia 60, 89-92.

Lepeduš, H., Štolfa, I., Radić, S. Ćurković Perica, M., Pevalek-Kozlina, B., Cesar, V., 2008: Photosynthetic electron transport and superoxide dismutase activity during natural senescence of maple leaves. Croatica Chemica Acta 81, 97-103.

LichtenthaleR, H. K., 1987: Chlorophyll and carotenoids: pigments of photosynthetic biomembranes. Methods in Enzymology 148, 350-382.

Matile, P., Hortensteiner, S., Thomas, H., Krautler, B., 1996: Chlorophyll breakdown in senescent leaves. Plant Physiology 112, 1403-1409.

MAXWELl, K., JohnSON, N., 2000: Chlorophyll fluorescence - a practical guide. Journal of Experimental Botany 51, 659-668.

Mendoza-Cózatl, D., Loza-Tavera, H., HernaÁndez-Navarro, A., Moreno-Sánchez, R., 2005: Sulfur assimilation and glutathione metabolism under cadmium stress in yeast, protests and plants. FEMS Microbiology Reviews 29, 653-671.

MitTLER, R., 2002: Oxidative stress, antioxidants and stress tolerance. Trends in Plant Science 7, 405-410.

Munné-Bosch, S., 2008: Do perennials really senesce? Trends in Plant Science 13, 216-220.

PfFAnNSCHMidT, T., 2003: Chloroplast redox signals: how photosynthesis controls its own genes. Trends in Plant Science 8, 33-41.

RAUSCH, T., WACHTER, A., 2005: Sulfur metabolism: a versatile platform for launching defence operation. Trends in Plant Science 10, 503-509. 
Lepeduš H., Begović L., Mlinarić S., Šimić D., Štolfa I., PARAĐiković N. et al.

RAYMOND, J., BlAnKEnShIP, R. E., 2008: The origin of the oxygen-evolving complex. Coordination Chemistry Reviews 252, 377-383.

Rodoni, S., Schellenber, M., Matile, P. 1998: Chlorophyll breakdown in senescing barley leaves as correlated with phaeophorbide $a$ oxygenase activity. Journal of Plant Physiology $152,139-144$.

Rodoni, S., Mühlecker, W., Anderl, M., KrÄutler, B., Moser, D., Thomas, H., Matile, P., Hörtensteiner, S., 1997: Chlorophyll breakdown in senescence chloroplasts: cleavage of pheophorbide $a$ in two enzymic steps. Plant Physiology 115, 669-676.

Schreiber, U., Bilger, W., Neubauer, C., 1994: Chlorophyll fluorescence as a nonintrusive indicator for rapid assessment of in vivo photosynthesis. In: Schulze, E. D., Caldwell, M. M. (eds.), Ecophysiology of photosynthesis. Ecology Studies 100, 49-70. Springer, Berlin.

SHAPOURI, H., DufFIELD, J., 1993: The economics of producing energy crops. Office of Energy, U.S. Department of Agriculture, Washington, D. C.

Sinclair, W. A., Lyon, H. H., Johnson, W. T., 1987: Diseases of trees and shrubs. Comstock Publishing Associates, Ithaca, N.Y.

Strasser, R. J., SRIVASTAVA, A., GovindJeE, 1995: Polyphasic chlorophyll a fluorescence transient in plants and cyanobacteria. Photochemistry and Photobiology 61, 32-42.

Strasser, R. J., Srivastava, A., Tsimilli-Michael, M., 2000: The fluorescent transient as a tool to characterise and screen photosynthetic samples. In: Yunus, M., PATHRE, U., Mohanty, P., (eds.), Probing photosynthesis: mechanisms, regulation and adaptation, 445-483. Taylor and Francis, London.

Strasser, R. J., Srivastava, A., Tsimilli-Michael, M., 2004: Analysis of chlorophyll $a$ fluorescence transient. In: PAPAgeorgiou, G. C., GovindjeE (eds.), Chlorophyll $a$ fluorescence a signature of photosynthesis: Advances in photosynthesis and respiration 19, 321-362, Kluwer Academic Publishers, Dordrecht.

Stirbet, A., Govindjee, Strasser, B. J., Strasser, R. J., 1998: Chlorophyll $a$ fluorescence induction in higher plants: Modelling and numerical simulation. Journal of Theoretical Biology 193, 131-151.

Suzuki, J. Y., Bollivar, D. W., BAuER, C. E., 1997: Genetic analysis of chlorophyll biosynthesis. Annual Review of Genetics 31, 61-89.

TAKahashi, S., Murata, N., 2008: How do environmental stresses accelerate photoinhibition? Trends in Plant Science 13, 178-182.

TANG, Y., WEN, X., LU, C., 2005: Differential changes in degradation of chlorophyll-protein complexes of photosystem I and photosystem II during flag leaf senescence of rice. Plant Physiology and Biochemistry 43, 193-201.

UŽArević, Z., ŠTolfa, I., PARAdŽIKović, N., Cesar, V., LePeduš, H., 2011: Physiology and biochemistry of leaves bleaching in prematurely aging maple (Acer saccharinum L.) trees: I. Hydrogen peroxide level, antioxidative responses and photosynthetic pigments content. Acta Botanica Croatica 70, 121-132.

Zarcinas, B. A., Cartwright, B., Spouncer, L. R., 1987: Nitric acid digestion and multi-element analysis of plant material by inductively coupled plasma spectrometry. Communications in Soil Science and Plant Analysis 18, 131-146. 